\title{
Zarządca sukcesyjny jako przedsiębiorca
}

\section{The successional administrator as an entrepreneur mgr Konrad Kopystyński}

\author{
E-mail: konrad.kopystynski@uwr.edu.pl; ORCiD: 0000-0003-3382-3110
}

\begin{abstract}
Streszczenie
Przedmiotem artykułu jest analiza statusu prawnego zarządcy sukcesyjnego pod kątem przesłanek definiujących przedsiębiorcę w rozumieniu Prawa przedsiębiorców. Bezsporne wydaje się, że zarządzanie przedsiębiorstwem w spadku nosi cechy zarobkowości, zorganizowania i ciągłości, w istocie stanowi bowiem kontynuację działalności wykonywanej uprzednio przez zmarłego przedsiębiorcę. Najwięcej wątpliwości w tym kontekście budzi przesłanka wykonywania działalności gospodarczej we własnym imieniu, i to pomimo ustawowego sformułowania, że zarządca sukcesyjny działa w imieniu własnym, na rachunek właściciela przedsiębiorstwa w spadku. W doktrynie wskazuje się jednak, że w istocie zarządca sukcesyjny nie dokonuje czynności w imieniu własnym, lecz w imieniu właściciela przedsiębiorstwa w spadku. Niemniej zarządcę sukcesyjnego należy uznać za przedsiębiorcę przynajmniej w odniesieniu do działalności polegającej na profesjonalnym świadczeniu usług w przedmiocie zarządzania przedsiębiorstwem w spadku.
\end{abstract}

Słowa kluczowe: zarządca sukcesyjny, przedsiębiorca, działalność gospodarcza

\section{Summary}

The subject of this article is an analysis of a legal status of the successional administrator from the perspective of premises of the economic activity within the meaning of provisions of the entrepreneurs law. Undisputedly, the administrating an enterprise in inheritance should be considered as a commercial, organized and continuous activity. In fact, that is a continuation of economic activity performed by a deceased entrepreneur. The most doubts are relating to the premise of performing on its own behalf. That is even though legal provisions literally provide that a successional administrator performs on his own behalf, but the same he performs on the owner's of enterprise in inheritance account. It is indicated in a doctrine that in fact the successional administrator performs not in his own behalf, but in owner's of enterprise in inheritance behalf. However, he should be considered as an entrepreneur at least in the scope of an activity which is consisting in professional providing services in the form of the administrating an enterprise in inheritance.

Key words: successional administrator, entrepreneur, economic activity

JEL: K20

Str. $18-24$

\section{Bibliografia}

Adamus, R. (2019). Prawo upadłościowe. Komentarz. Warszawa: C.H. Beck.

Bieluk, J. (2019). Ustawa o zarządzie sukcesyjnym przedsiębiorstwem osoby fizycznej. Komentarz. Legalis.

Bierć, A. (1998). Osoba fizyczna jako przedsiębiorca. Studia Prawnicze, (4), 5-61.

Bierć, A. (1999). Sytuacja prawna przedsiębiorcy. Zagadnienia wybrane. Studia Prawnicze, (3), 5-69.

Brożyna, M., Kohutek, K., Molis, J., Szuster, S. (2005). Swoboda działalności gospodarczej. Komentarz. LEX.

Ereciński, T. (red.). Gudowski, J. (2016). Kodeks postępowania cywilnego. Komentarz (t. 4). Warszawa: Wolters Kluwer.

Frąckowiak, J. (2018). W: J. Rajski (red.). System Prawa Prywatnego (t. 7). Prawo zobowiązań - część szczególowa. Warszawa: C.H. Beck.

Gawrylczyk, W. (2000). Przedstawicielstwo. Monitor Prawniczy, (12), 760-767.

Gniewek, E. (2014). W: Gniewek, E. (red.), Machnikowski, P. (red.). (2014). Kodeks cywilny. Komentarz. Warszawa: C.H. Beck.

Gronkiewicz-Waltz, H., Jaroszyński, K. (2017). W: H. Gronkiewicz-Waltz (red.), M. Wierzbowski (red.). Prawo gospodarcze. 
Zagadnienia admi- nistracyjnoprawne. Warszawa: Wolters Kluwer.

Grzybczyk, G. (1998). Różne formy pośrednictwa. Rejent, (2), 45-58.

Jezioro, J. (2004). W: E. Gniewek (red.). Kodeks cywilny. Komentarz. Warszawa: C.H. Beck.

Katner, W. J. (2003). Prawo działalności gospodarczej. Komentarz. Warszawa: Lexis Nexis.

Kocowski, T. (2018). W: R. Hauser, (red.), Z. Niewiadomski (red.), A. Wróbel (red.). System Prawa Administracyjnego (t. 8A). Publiczne prawo gospodarcze. Warszawa: C.H. Beck

Kopaczyńska-Pieczniak, K. (2018). Status prawny zarządcy sukcesyjnego. Przeglad Prawa Handlowego, (12), 4-11.

Kosikowski, C. (2009). Ustawa o swobodzie działalności gospodarczej. Komentarz. Warszawa: Lexis Nexis.

Miczek, Z. (2005). Osoba fizyczna jako przedsiębiorca - na tle ustawy o swobodzie działalności gospodarczej i kodeksu cywilnego. Przeglad Pra- wa Handlowego, (9), 24-28.

Odachowski, J. (2003). Ciągłość działalności gospodarczej. Glosa, (10), 30-33.

Pawełczyk, M. (2007). W: A. Powałowski (red.). Ustawa o swobodzie działalności gospodarczej. Komentarz. Warszawa: ABC a Wolters Kluwer bu- siness.

Sieradzka, M. (2018). Zarząd sukcesyjny przedsiębiorstwem osoby fizycznej — analiza i ocena nowych rozwiązań prawnych (cz. 2). Monitor Prawniczy, (23), 1242-1250.

Stoga K. (2000). W: J. Sommer, K. Stoga, R. Potrzeszcz. Prawo działalności gospodarczej, Warszawa: Twigger.

Strzyczkowski, K. (2005). Prawo gospodarcze publiczne. Warszawa: Lexis Nexis.

Szczurowski, T. (2018). Zarząd sukcesyjny przedsiębiorstwem w spadku. Przeglad Ustawodawstwa Gospodarczego, (11), 31-36.

Szydło, M. (2005). Swoboda działalności gospodarczej. Warszawa: C.H. Beck.

Zdyb, M. (2000). Prawo działalności gospodarczej. Komentarz. Kraków: Zakamycze.

Zimmerman, P. (2018). Prawo upadlościowe. Komentarz. Warszawa: C.H. Beck.

Ustawa z 25.02.1964 r. - Kodeks rodzinny i opiekuńczy (Dz.U. z 2017 r. poz. 682 ze zm.).

Ustawa z 23.04.1964 r. - Kodeks cywilny (Dz.U. z 2018 r. poz. 1025 ze zm.).

Ustawa z 28.02.2003 r. — Prawo upadłościowe (Dz.U. z 2019 r. poz. 498 ze zm.).

Ustawa z 6.03.2018 r. — Prawo przedsiębiorców (Dz.U. poz. 646 ze zm.).

Ustawa z 5.07.2018 r. o zarządzie sukcesyjnym przedsiębiorstwem osoby fizycznej (Dz.U. poz. 1629).

Uzasadnienie projektu ustawy o zarządzie sukcesyjnym przedsiębiorstwem osoby fizycznej, Sejm VIII kadencji, druk nr 2293.

Wyrok SA w Katowicach z 14.12.1995 r., I ACr 712/95, Legalis nr 33882.

Wyrok WSA we Wrocławiu z 27.04.2005 r., I SA/Wr 3237/03, LEX nr 496830. 